
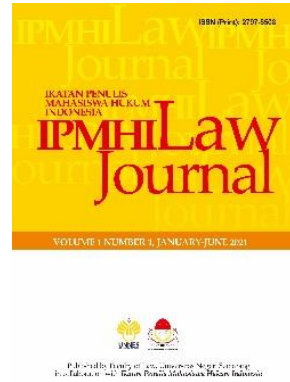

ISSN 2797-8508 (Print) ISSN 2807-8330 (Online)

VOL. 2 NO. 2, JUL-DEC (2022)

Riwayat Artikel

History of Article

Diajukan: 17 Mei 2022 Submitted

Direvisi: 11 Juni 2022

Revised

Diterima: 13 Juli 2022

Accepted

\title{
Saran Perujukan
} How to cite:

Kurniawan, T. (2022). Urgensi Pengesahan Rancangan Undang Undang Perlindungan Data Pribadi Dalam Digitalisasi Pelayanan Publik Guna Mewujudkan Smart Government. Ikatan Penulis Mahasiswa Hukum Indonesia Law Journal, 2(2). https://doi.org/10.15294/ipmhi.v2i2.55032

(C) 2022 Authors. This work is licensed under a Attribution-NonCommercial-ShareAlike 4.0 International (CC BY-NC-SA 4.0). All writings published in this journal are personal views of the authors and do not represent the views of this journal and the author's affiliated institutions. This title has been indexed by Google Scholar

\section{Urgensi Pengesahan Rancangan Undang- Undang Perlindungan Data Pribadi Dalam Digitalisasi Pelayanan Publik Guna Mewujudkan Smart Government} The Urgency of Ratification of the Personal Data Protection Bill in Digitizing Public Services to Realize Smart Government

Teguh Kurniawan ${ }^{1}$, Natalia Carolina Simanjuntak ${ }^{2}$, Sri Uliana Limbong ${ }^{3}$

1 Universitas Sumatra Utara

2 Universitas Sumatra Utara

3 Universitas Sumatra Utara

Email Korespondensi: kurniawan012001@students.usu.ac.id

Abstract Smart city is a form of part of the vision of city development in creating integrity through information and communication technology (ICT) and Internet 
of Things (IoT) solutions for regional data security-based governance measures. One of the elements that build the creation of a Smart City is the implementation of e-government. In relation to public services, the implementation of egovernment is the integration of information technology and the internet to provide public services. This is aimed at realizing good and professional public services. In the digitalization of public services, we are faced with a problem related to guaranteeing the protection and security of digital data. Digital data is something that is risky related to misuse by unauthorized persons and leads to criminal acts. Unfortunately, the current regulations relating to the protection of personal data in Indonesia are only partial and sectoral, so they cannot protect them effectively and efficiently, as this data is also private in nature. The problems in this paper are: 1) How is the Role of Digitizing Public Services in Realizing Smart Government 2) How is the Urgency of Ratification of the Personal Data Protection Bill on Digital-Based Public Services. This study uses a normative juridical research method using a statutory approach as well as a conceptual approach. The data used in this study is secondary data that acts as the main data and uses the Library Study model as a material collection technique. All material collected will be carried out an inventory, classification, and analysis using a descriptive analysis model whose purpose is to provide a description of the problem so that innovative solutions are obtained. With the ratification of the Personal Data Protection Bill, it can improve the existing rules on personal data protection and be able to guarantee optimal legal certainty for the protection of citizens' personal data.

\section{Keywords Personal Data; Public Service; Smart Government}

Abstrak Kota pintar (Smart city) ialah sebuah bentuk dari potongan visi pembangunan kota dalam menciptakan integritas melalui teknologi informasi dan komunikasi (TIK)dan solusi Internet of Things (IoT) guna langkah tata kelola berbasis keamanan data wilayah. Salah satu unsur yang membangun terciptanya Smart City ialah diterapkannya e-government. Kaitannya dengan pelayanan publik, penerapan e-government merupakan pengintegrasian antara teknologi informasi dan internet guna menyelenggarakan layanan publik. Hal ini bertujuan guna mewujudkan layanan publik yang baik dan profesional. Dalam digitalisasi layanan publik dihadapkan pada sebuah masalah terkait dengan jaminan perlindungan dan keamanan data digital. Data digital menjadi sesuatu yang riskan terkait penyalahgunaan bagi oknum yang tidak berkepentingan dan menjurus kepada tindakan kejahatan. Mirisnya, pengaturan yang berhubungan dengan perlindungan data pribadi saat ini di Indonesia sifatnya hanya parsial dan sektoral sehingga tidak dapat melindungi secara naik dan tepat guna, sebagaimana data ini sifatnya juga privasi. Adapun permasalahan dalam karya tulis ini yaitu: 1) Bagaimana Peran Digitalisasi Pelayanan Publik dalam Mewujudkan Smart Government 2) Bagaimana Urgensi Pengesahan Rancangan Undang Undang Perlindungan Data Pribadi pada Pelayanan Publik Berbasis Digital. Penelitian ini memakai Jenis penelitian yuridis normatif dengan menggunakan metode 
pendekatan peraturan perundang-undangan serta pendekatan konseptual. Data yang dipakai dalam penelitian ini ialah data sekunder berperan sebagai data utamanya serta memakai model Studi Kepustakaan sebagai teknik pengumpulan bahan. Semua materi yang terkumpul nantinya akan dilakukan inventarisasi, klasifikasi, dan analisis dengan memakai model analisis deskriptif yang tujuannya guna memberikan uraian permasalahan sehingga didapatkan solusi inovatif. Dengan disahkannya Rancangan Undang Undang Perlindungan Data Pribadi bisa menyempurnakan aturan tentang perlindungan data pribadi yang sudah ada serta mampu menjamin kepastian hukum yang optimal bagi perlindungan data pribadi warga negara.

\section{Kata kunci Data Pribadi; Pelayanan Publik; Smart Government}

\section{A. Pendahuluan}

Smart city diartikan secara umum dengan suatu wilayah kota pintar dengan model tata kelola yang sistematis dengan tujuan utamanya untuk kepentingan masyarakat dan dapat mengelola sumber daya dengan baik dan tepat. ${ }^{1}$ Beberapa kota yang mendapat sebutan smart city ialah wilayah yang awalnya mempunyai ide kreatif untuk menyelesaikan sebuah permasalahan yang ada serta mampu menaikkan derajat kotanya. Adapun pandangan yang menjadi sorotan dalam smart city ialah pelayanan yang diberikan ini berbasis teknologi terbaru dan pintarnya bentuk infrastruktur, yang mana ini bisa melayani masyarakat dengan mudah dan terjangkau bagi semuanya.

Salah satu unsur yang membangun terciptanya smart city ialah penerapan $e$ government. Banyak definisi terkait e-government, satu diantaranya ialah bentuk nyata dari penggunaan teknologi informasi pada sektor publik guna membentuk sebuah alur interaksi terbaru pemerintah dengan semua elemen (lembaga pemerintah, warga, bisnis) yang tujuannya agar tersedianya akses informasi secara luas, layanan publik yang berkualitas, serta kesempatan untuk berpartisipasi dalam proses penyelenggaraan pemerintah. ${ }^{2}$ Konsep smart government berkaitan dengan salah satu aspek terpenting dari kota, yakni pengembangan instansi pemerintahan atau badan yang didasarkan pada teknologi informasi yang dimanfaatkan supaya bisa digapai oleh pihak yang mempunyai kepentingan secara cepat dan tepat.

Selain itu, diantara indikator keberhasilan penerapan smart government ialah pelayanan publik yang optimal. Belakangan ini adanya permasalahan yang dihadapi oleh sistem pelayanan publik dengan maraknya keadaan yang jauh dari kebutuhan warganya dan dipengaruhi oleh berubahnya model kehidupan kebangsaan, kemasyarakatan, dan kenegaraan. Kondisi demikian ini karena tidak siapnya

1 Abdurrozzaq Hasibuan Dan Oris Krianto Sulaiman. 2019. Smart City, Konsep Kota Cerdas Sebagai Alternatif Penyelesaian Masalah Perkotaan Kabupaten/Kota, Di Kota-Kota Besar Provinsi Sumatera Utara. Jurnal Buletin Utama Teknik. Volume 14 Nomor 2. hlm. 127.

2 Deni Napitupulu. (2020). E-Government: Implementasi, Strategi dan Inovasi. Medan: Yayasan Kita Menulis. hlm. 5. 
pemerintah dalam mengkombinasikan secara terpadu antara pelayanan publik dengan e-government. Salah satu bentuk ketidaksiapan pemerintah adalah dalam menjamin keamanan data digital dalam digitalisasi pelayanan publik.

Masalah terbesar dari setiap pemanfaatan teknologi informasi dan komunikasi ialah kaitannya dengan sistem keamanan "privacy", perlunya kelayakan guna memberikan jaminan akan m melindungi data pribadi ini pada sistem elektronik utamanya pada penerapan e-government. ${ }^{3}$ Pemerintah perlu memberikan perhatian khusus yang berkaitan dengan penerapan e-government, hal ini apalagi berhubungan di dalam sektor publik yang notabene rentan akan terjadinya pembajakan data dan nantinya ketika kasus ini muncul akan memberikan dampak pada kepercayaan masyarakat terkait program yang digalakkan ini. Ada bermacam pelanggaran yang mungkin bisa terjadi di media sosial, tetapi lebih berbahaya lagi jikalau pelanggaran ini akan menyerang sistem e-government. ${ }^{4}$ Salah satu contoh kasus kebobolan data pribadi digital yang berkaitan dengan layanan publik yaitu dialami oleh Badan Penyelenggara Jaminan Sosial atau BPJS Kesehatan. Terjadi sekitar Mei 2021, ada kurang lebih 279 juta data penduduk Indonesia yang ikut dalam program BPJS Kesehatan datanya kebobol serta terjual pada situs raidsforum.com. pada data tersebut terdapat beberapa informasi yang terkait dengan beberapa catatan kesehatan, pendidikan, kerja sosial, ataupun beberapa data yang memang relevan adanya dan disimpan di dalamnya. Bentuk perlindungan data dapat kita lihat dari adanya aturan yang membahas terkait dengan pemakaian data guna dimanfaatkan dan dirusak oleh orang yang memakainya. ${ }^{5}$

Sejauh ini negara Indonesia belum memberikan legalitas yang valid dan terjamin akan perlindungan data pribadi khususnya, padahal posisinya kebijakan ini memang sangat diperlukan demi keamanan dan kenyamanan warga. Jaminan hukum ini perlu pemerintah berikan, karena akan berkaitan dengan penerapan sistem e-government mendatang, dengan sistem aman yang terjamin dan masyarakat percaya akan data yang diberikan itu bisa digunakan dengan baik maka bisa berdampak pada tingginya kepercayaan masyarakat terhadap pemerintah khususnya digitalisasi reformasi birokrasi yang dilaksanakan. ${ }^{6}$

Masyarakat mengharapkan adanya jaminan hukum yang pasti untuk mereka, hal ini karena pemerintah memang wajib memberikan jaminan akan hak yang dimiliki warganya utamanya demi kelancaran pelaksanaan program smart

3 Danrivanto Budhijanto. (2016). Revolusi Cyberlaw Indonesia Pembaharuan dan Revisi UU ITE. Bandung: Refika Aditama, hlm.140.

4 Sinta Dewi Rosadi. (2015). Cyberlaw Aspek Data Privasi Menurut Hukum Internasional, Regional, dan Nasional. Bandung: Refika Aditama, hlm. 12.

5 Sautunnida. (2018). Urgensi Undang-Undang Perlindungan Data Pribadi di Indonesia: Studi Perbandingan Hukum Inggris dan Malaysia. Kanun Jurnal Ilmu Hukum, Volume 20 Nomor 2, hlm. 369.

6 Lis Febrianda. (2009). Rekonstruksi Regulasi Pelayanan Kependudukan dan Pencatatan Sipil oleh Birokrasi Pemerintahan dalam Perspektif Hukum Administrasi Negara. Semarang: Disertasi Universitas Diponegoro, hlm. 84. 
government. Perlindungan data pribadi dalam bingkai pelaksanaan smart government merupakan hak privasi warga negara yang harus dilindungi dan dilaksanakan sebagaimana ditegaskan pada konstitusi yang pada pokoknya menyebutkan bahwasannya masing-masing manusia memiliki hak atas diri pribadi utamanya perlindungan. Perlindungan diri pribadi disini juga dimaksudkan untuk melindungi kerahasiaan atau privasi seseorang.

Berangkat dari uraian di atas, terdapat permasalahan bahwa urgensi dari pengesahan rancangan undang-undang perlindungan pribadi semakin tinggi mengingat sendi-sendi kehidupan masyarakat tidak lepas dari kegiatan administratif yang mana pada saat ini dalam kaitannya dengan pelaksanaan $e$ government memindahkan seluruh data-data pribadi penduduk ke dalam suatu sistem online yang rentan mengalami kebocoran dan penyalahgunaan data. oleh karenanya, penulis berminat guna mengupas kaitannya Urgensi Pengesahan Rancangan Undang Undang Perlindungan Data Pribadi Dalam Digitalisasi Pelayanan Publik Guna Mewujudkan Smart Government.

\section{B. Metode}

Metode penelitian hukum yuridis normatif yang dipakai dalam penelitian ini. ${ }^{7}$ Penelitian yuridis normatif ialah model penelitian hukum kepustakaan yang mana dijalankan dengan sistem awal meneliti beberapa data sekunder belaka utamanya bahan pustaka. Jenis data yang dipakai terkait dengan bahan hukum utama misalnya aturan perundang undangan yaitu UUD Negara Republik Indonesia Tahun 1945, RUU Perlindungan Data Pribadi, UU No. 25 Tahun 2016 tentang Pelayanan Publik, UU No. 14 tahun 2008 tentang Keterbukaan Informasi Publik, UU No. 24 Tahun 2013 tentang UU Administrasi Kependudukan, UU No. 19 Tahun 2016 tentang Informasi dan Transaksi Elektronik, UU No. 36 Tahun 2009 tentang Kesehatan, Peraturan Pemerintah No. 18 Tahun 2012 tentang Penyelenggaraan Sistem dan Transaksi, Instruksi Presiden No. 3 Tahun 2003 tentang Kebijakan dan Strategi Nasional Pengembangan E- Government, Peraturan Menteri Komunikasi dan Informatika No. 20 Tahun 2016 tentang Perlindungan Data Pribadi dalam Sistem Elektronik dimana keterkaitan aturan ini dengan pelayanan publik yang mana erat hubungannya dengan data pribadi, bahan hukum sekunder, dan bahan hukum tersier. Selaras pada jenis penelitian yang dipakai itu yuridis normatif, maka pada penelitian ini pendekatan yang dipakai ialah pendekatan perundang-undangan (statute approach) serta pendekatan konseptual (conceptual approach). Pendekatan perundang- undangan (statute approach) ${ }^{8}$ ialah pendekatan yang lebih mengawalinya dengan penggunaan bahan hukum berbentuk aturan perundangundangan ataupun konvensi internasional yang memiliki keterkaitan dengan jurnal

Soerjono Soekanto. (2007). Pengantar Penelitian Hukum. Jakarta: UI Press, hlm. 15.

8 Peter Mahmud Marzuki. (2011). Penelitian Hukum, Jakarta: Kencana Prenada Media Group, hlm. 96. 
ini untuk nantinya dijadikan bahan pedoman guna melaksanakan proses penelitian. Pendekatan konseptual (conceptual approach) ${ }^{9}$ ialah model pendekatan yang menitikberatkan pada pemberian pandangan atau dengan model permasalahan tersebut dianalisis lebih dahulu atas dasar hukum yang dipandang dari latar belakang aspek beberapa konsepan hukum, atau dipandang dari beberapa nilai yang ada di dalam norma suatu aturan yang kaitannya dengan beberapa konsep yang akan dipakai. Adapun library research atau studi kepustakaan dipakai dalam sistem pengumpulan datanya. Pemakaian sistem ini dikarenakan guna memperoleh dasar dalam proses analisa beberapa data yang terkumpul dari banyaknya sumber terpercaya dan bisa dipertanggung jawabkan, baik itu langsung ataupun tidak. Sehingga bisa didapatkan simpulan yang arahnya jelas dan tidak keluar dari pembahasan. Studi dokumen yang kaitanya dengan topik penulisan menjadi alat pengumpulan data pada penelitian ini. Semua bahan hukum sudah bisa terkumpul, berikutnya dilakukan proses inventarisasi, klasifikasi dengan memakai metode deskriptif analitis, yakni sebuah metode yang dipakai guna pembelajaran akan masalah yang ada di masyarakat, dan juga kaitannya dengan situasi dan keseharian kebiasaan yang berlaku di dalamnya. ${ }^{10}$

\section{Hasil dan Pembahasan}

\section{Peran Digitalisasi Pelayanan Publik Dalam Mewujudkan Smart Government}

Pelayanan publik didefinisikan dengan sebuah upaya yang diperbuat oleh orang atau kelompok atau instansi terkait dalam memudahkan dan memberikan pertolongan pada masyarakat guna mewujudkan tujuan yang sudah direncanakan. ${ }^{11}$ Moenir mengartikan pelayanan dengan aktivitas yang dijalankan oleh individu atau kelompok manusia dengan dasar tertentu, yang mana hanya bisa berdampak pada orang yang merasa melayani atau dilayani, berdasarkan kapasitas pemberi layanan dalam memenuhi pengguna layanan. ${ }^{12}$

Jika mengacu kepada Undang Undang Pelayanan Publik, yang memberikan pengertian bahwa pelayanan publik ialah aktivitas yang tujuanya untuk pemenuhan kebutuhan pelayanan atas barang dan jasa, serta layanan administratif yang selaras dengan hukum yang sudah ditentukan dan berlaku. ${ }^{13}$ Bahwa pada kasus ini negara wajib menjalankan pemenuhan layanan bagi setiap warga masyarakat guna pemenuhan akan keperluan dan kebutuhan pokoknya yang mana ini tertuang pada UUD Negara Republik Indonesia Tahun 1945.

Oleh karenanya, esensi pelayanan publik adalah sebagai hasil pemerintahan yang dipromosikan untuk masyarakat banyak (being marketed to public), tetapi

9 Johnny Ibrahim. (2007). Teori dan Metodologi Penelitian Hukum Normatif, Malang: Bayu Media, hlm. 391.

10 Moh Nazir. (2005). Metode Penelitian. Jakarta: Ghalia Indonesia, hlm. 35

11 Nashuddin. (2016). Manajemen \& Kepemimpinan dalam Pelayanan Publik. NTB: Sanabil, hlm. 113.

12 Djafri Novianty. (2018). Manajemen Pelayanan (Berbasis Revolusi Mental). Gorontalo: Ideas Publishing, hlm. 19.

13 Lihat Pasal 1 angka 1 Undang Undang Nomor 25 Tahun 2009 tentang Pelayanan Publik 
harus berorientasi pada budaya pelayanan (service culture) dengan langkah untuk menciptakan pelayanan yang memuaskan kepada masyarakat (creating service through customer satisfaction). Maka dari itu, dibutuhkan kualitas pelayanan yang maksimal (high quality service) serta pengadaan beberapa pusat layanan yang bisa memberikan pemenuhan standar performa dan desain lengkap lewat pengolahan data yang masuk perangkat keras serta lunak (hardware dan software) yang mendukung. ${ }^{14}$

Pada proses pelaksanan pelayanan publik dan beberapa asas yang dipedomani dalam melaksanakan layanan kepada masyarakat diantaranya:

1) Transparansi, yakni sifatnya terbuka, gampang serta bisa dilakukan akses oleh seluruh orang yang memerlukan, tersedia secara layak, dan bisa dipahami oleh semuanya.

2) Akuntabilitas, yakni bisa dipertanggungjawabkan yang mana ini selaras dengan aturan perundang-undangan.

3) Kondisional, yakni selaras dengan keadaan serta ketanggapan pemberi dan penerima layanan yang mana bisa berpedoman pada prinsip kebaikan dan ketepatan.

4) Partisipatif, yakni mendukung peranan warga akan pelaksanaan pelayanan masyarakat dalam bentuk perhatian berupa aspirasi, harapan, kritik maupun sarannya.

5) Kesamaan hak, yakni posisi warga sama, tidak adanya perbedaan ras, agama, suku, golongan dan bahkan status ekonomi.

Smart government adalah sebuah elemen utama yang berkaitan erat dalam menciptakan sebuah kota yang cerdas (smart city). Smart city ialah strategi tentang visi pembangunan serta pengembangan perkotaan dengan mengintegrasikan peran serta teknologi informasi dan komunikasi dan solusi Internet of Things (IOT) pada sebuah upaya dalam mengelola aset kota.

Dengan mengintegrasikan penggunaan teknologi informasi dan internet dalam konsep smart city, maka dapat meningkatkan kualitas hidup warga masyarakat kota, secara aman dan nyaman. Ada beberapa unsur yang membangun konsep smart city yaitu: 15

1. Pembangunan ekonomi secara cerdas (smart economy)

2. Mobilitas atau pergerakan yang mumpuni (smart mobility)

3. Pengelolaan lingkungan secara cerdas (smart environment)

4. Kualitas sumber daya manusia (smart people)

5. Kehidupan yang berkualitas (smart living)

6. Tata kelola pemerintahan yang cerdas (smart government)

Salah satu indikator utama dalam mewujudkan smart government adalah pengintegrasian sistem berbasis elektronik atau digital pada pelayanan publik. Dengan mengintegrasikan sistem berbasis elektronik ke dalam penyelenggaraan pelayanan publik menjadikan pelayanan publik berkualitas, efektif, dan efisien.

Dalam konsep negara kesejahteraan (welfare state), pelayanan publik sebagai sebuah bentuk upaya yang dilakukan oleh birokrasi publik yang kaitannya dengan perwujudan keadilan dan kemakmuran warganya. Melalui pelayanan publik, warga

14 Lis Febrianda, Op.Cit., hlm. 94.

15 Chandra Eko Utomo \& Hariadi. (2016). Strategi Pembangunan Smart City dan Tantangannya bagi Masyarakat Kota. Jurnal Strategi dan Bisnis. Volume 4 Nomor 2, hlm. 12. 
masyarakat dapat terpenuhi kebutuhannya dalam menjalani kehidupan sosial dan ekonomi sehingga setiap orang berhak memperoleh pelayanan publik sebagai haknya. ${ }^{16}$

Dewasa ini, arus perkembangan teknologi informasi memberikan pengaruh signifikan terhadap perubahan di berbagai aspek, tidak terkecuali dalam penyelenggaraan pelayanan publik. Perubahan yang terjadi yaitu adanya pergeseran dari pelayanan publik berbasis konvensional menjadi digital yang ditandai dengan penggunaan internet of things (IoT) dalam pelaksanaan pelayanan publik. $^{17}$

Pelaksanaan pelayanan publik berbasis konvensional dilaksanakan tanpa melibatkan unsur teknologi dan internet dalam pemenuhan layanan kepada masyarakat. Dalam pelaksanaan pelayanan publik secara konvensional, seringkali masyarakat dihadapkan kepada urusan pelayanan dengan antrian yang panjang, lama, boros biaya, berbelit belit, koruptif, diskriminatif, dan tidak responsif.27 Jika melihat data yang dikeluarkan oleh Ombudsman RI sebagai pengawas eksternal pelayanan publik, pada tahun 2016 jumlah laporan masyarakat terkait dengan pelayanan publik mencapai 10.000 laporan. ${ }^{18}$

Dari 10.000 laporan terhadap Ombudsman diantaranya mengenai tindakan pungutan liar, penundaan pelayanan publik, dan penyalahgunaan kewenangan. Dari total 10.000 laporan pada tahun 2016, sekitar 7 persennya adalah laporan tentang pungutan liar dalam pelayanan publik. ${ }^{19}$ Pungutan liar terjadi terjadi diawali oleh adanya penundaan layanan publik yang mengharuskan masyarakat untuk membayar sejumlah uang agar dapat mempercepat urusan atau keperluan dalam layanan publik. ${ }^{20} \mathrm{Hal}$ ini menunjukkan rendahnya implementasi terhadap standarisasi pelayanan publik di Indonesia sehingga menyebabkan kualitas layanan publiknya rendah.

Kualitas yang rendah pada sistem pelayanan publik dapat memberikan dampak akan tingginya biaya perekonomian, menghambat tumbuhnya investasi serta memberikan efek kepercayaan publik yang rendah pada tata kelola efektivitas pemerintahan dan berpotensi menimbulkan apatisme publik. Selain itu, penyimpangan-penyimpangan yang terjadi dalam layanan publik juga cenderung menimbulkan tindakan koruptif. ${ }^{21}$ Tindakan koruptif tersebut mengakibatkan

16 Agus Widiyarta. (2012). Pelayanan Kesehatan Dari Perspektif Participatory Governance (Studi Kasus Tentang Partisipasi Masyarakat dalam Pelayanan Dasar Kesehatan Di Kota Surabaya), Disertasi Program Doktor Ilmu Administrasi Fakultas Ilmu Administrasi. Malang: Universitas Brawijaya Press , hlm. 4.

17 Rudy Rinaldy. Manfaat Teknologi Informasi dalam Pelayanan Publik. https://padang.go.id/manfaat-teknologi-informasi-dalam-pelayanan-publik diakses pada 1 Oktober 2021.

18 Andrian Pratama Taher. 2016. Rapor Merah Pelayanan Publik. https://tirto.id/rapormerahpelayanan-publik-di-indonesia-b8zr diakses pada 1 Oktober 2021.

19 Lagat Parroha Patar. (2021). Proses Panjang Peningkatan Kualitas Nilai Pelayanan Publik di Indonesia. https://ombudsman.go.id/artikel/r/artikel--proses-panjang-peningkatankualitasnilai-pelayanan-publik-di-indonesia diakses pada 3 Oktober 2021.

20 Lagat Parroha Patar. (2021). Proses Panjang Peningkatan Kualitas Nilai Pelayanan Publik di Indonesia. https://ombudsman.go.id/artikel/r/artikel--proses-panjang-peningkatankualitasnilai-pelayanan-publik-di-indonesia diakses pada 3 Oktober 2021 .

21 Wahyu Ramadhani. (2017). Penegakan Hukum Menanggulangi Pungutan Liar terhadap Pelayanan Publik. Jurnal Samudra Keadilan. Volume 12 Nomor 2, hlm. 265. 
terjadinya inefisiensi birokrasi dan kualitas pelayanan publik menjadi rendah. Akibat akibat tersebut pada akhirnya dapat menghambat perwujudan smart government di Indonesia.

Dibawah ini turut disertakan tabel yang menggambarkan bagaimana antara realita pelayanan publik yang dilakukan secara konvensional dengan pemenuhan standarisasi pelayanan publik tidak terwujud.

\begin{tabular}{|c|c|c|c|}
\hline No & $\begin{array}{l}\text { Standarisasi } \\
\text { Pelayanan } \\
\text { Publik }\end{array}$ & $\begin{array}{l}\text { Hal yang ingin } \\
\text { dicapai (das sollen) }\end{array}$ & $\begin{array}{l}\text { Realita dalam Pelayanan } \\
\text { Publik Berbasis Konvensional } \\
\text { (das } \\
\text { sein) }\end{array}$ \\
\hline 1 & Transparansi & $\begin{array}{l}\text { a. Pelayanan sifatnya } \\
\text { terbuka } \\
\text { b. Kemudahan akses } \\
\text { c. Tersedia dengan } \\
\text { sangat layak } \\
\text { a. d. Dipahami } \\
\text { dengan gampang }\end{array}$ & $\begin{array}{l}\text { Pelayanan yang rumit, } \\
\text { tertutup, aksesnya susah, } \\
\text { kurang informatif dan tidak } \\
\text { layak }\end{array}$ \\
\hline 2 & Akuntabilitas & $\begin{array}{l}\text { a. Adanya } \\
\text { pertanggungjawab } \\
\text { an akan layakanan } \\
\text { yang diberikan } \\
\text { b. Mengikuti } \\
\text { ketentuan aturan } \\
\text { yang berlaku }\end{array}$ & $\begin{array}{l}\text { Pelayanan tidak dapat } \\
\text { dipertanggungjawabkan } \\
\text { secara kualitas dan moril dan } \\
\text { tidak sesuai dengan aturan }\end{array}$ \\
\hline 3 & Kondisional & $\begin{array}{l}\text { a.Layanan mengikuti } \\
\text { keadaan serta } \\
\text { kesanggupan } \\
\text { pemberi serta } \\
\text { penerima layanan } \\
\text { b.Berpedoman pada } \\
\text { prinsip efisiensi dan } \\
\text { efektivitas }\end{array}$ & $\begin{array}{l}\text { Tidak sama dengan } \\
\text { kesanggupan pelanggan, } \\
\text { biayanya banyak dan } \\
\text { menghabiskan waktu. }\end{array}$ \\
\hline 4 & Partisipatif & $\begin{array}{ll}\text { a. } & \text { Pelayanan bisa } \\
& \text { mendukung peran } \\
\text { serta warganya } \\
\text { b. } \\
\text { Memahami akan } \\
\text { suara masyarakat } \\
\text { c. } \\
\text { Kebutuhan dan } \\
\text { harapan yang bisa } \\
\text { tercapai }\end{array}$ & $\begin{array}{l}\text { a. Masyarakat menjadi apatis } \\
\text { b. Aspirasi tidak didengar } \\
\text { c. Harapan tidak sesuai } \\
\text { dengan } \\
\text { warganya. }\end{array}$ \\
\hline 5. & $\begin{array}{l}\text { Persamaan } \\
\text { hak }\end{array}$ & $\begin{array}{l}\text { a. } \text { Tidak } \\
\text { diskriminatif } \\
\text { dalam SARA dan } \\
\text { status sosial } \\
\text { b. Tidak nepotisme }\end{array}$ & $\begin{array}{l}\text { a. Terjadi diskriminatif } \\
\text { b. Pelayanan sering berdasar } \\
\text { kedekatan hubungan } \\
\text { teman/kerabat } \\
\text { (nepotisme) }\end{array}$ \\
\hline
\end{tabular}


Oleh karena itu, untuk menyelesaikan berbagai persoalan yang terjadi dalam pelayanan publik yang dilakukan secara konvensional serta mendukung terciptanya konsep smart government di Indonesia maka penulis dengan ini mengemukakan ide tentang digitalisasi pelayanan publik. Dalam konsep smart government, salah satu pilar utama dalam mewujudkannya adalah pengintegrasian aspek teknologi dan internet dalam menyelenggarakan layanan publik.

Terkait dengan digitalisasi pelayanan publik bisa membuat pelayanan publik menjadi lebih maju, pemenuhan layanan menjadi cepat, mudah, terjangkau, berkualitas, memberikan kemudahan akses bagi masyarakat, serta hasil akan pelayanan publik ini bisa lebih baik dan hemat dari segi waktu, biaya, serta tenaga. ${ }^{22}$ Artinya tidak ada lagi proses pelayanan publik yang berbelit belit, menimbulkan kebingungan, dan proses antrian yang panjang dalam pengurusannya. Digitalisasi pelayanan publik juga dapat dapat menciptakan jalinan yang harmonis antara eksekutif dengan bisnis, mewujudkan kecepatan dalam manajemen pemerintahan, serta memberdayakan potensi masyarakat.

Instruksi Presiden Nomor 3 tahun 2003 menjelaskan bahwa upaya mengembangkan e-government menjadi sebuah langkah dalam hal penerapan pelaksanaan pemerintahan yang basisnya elektronik pada kaitanya dengan peningkatan layanan publik yang berkualitas, cepat, dan tepat. Upaya perbaikan $e$ government dilaksanakan dengan perbaikan model manajemen serta kinerja pada sistem pemerintahan dengan memaksimalkan teknologi dan informasi dengan cakupan 2 (dua) kegiatan yang saling berhubungan yakni mengelola data serta manajemen informasi dengan sistem elektronik dan memaksimalkan akan majunya teknologi informasi untuk memudahkan warganya mengakses program. ${ }^{23}$

Sedangkan pada Peraturan Presiden No. 95 Tahun 2018 tentang Sistem Pemerintahan Berbasis Elektronik dalam tulisan menimbang dijelaskan bahwasannya guna mendukung perwujudan akan kebersihan, efektifitas, transparansi, dan akuntabilitas pengelolaan pemerintahan dan keramahan serta profesionalitas layanan publik diperlukan model pemerintahan dengan basis elektronik. ${ }^{24}$ Sistem pemerintahan dengan basis elektronik merupakan model pelaksanaan pemerintahan yang mengintegrasikan teknologi informasi dalam pemenuhan layanan kepada pengguna masyarakat.

Pada akhirnya, penyelenggaraan pelayanan publik berbasis digital diharapkan dapat memberikan kepuasan bagi masyarakat selaku pengguna layanan publik dalam mengurus kepentingan atau keperluannya. Sehingga dengan peningkatan

22 Bakti Kominfo. (2019). Seberapa Penting Pelayanan Publik Digital?. https://www.baktikominfo.id/id/informasi/pengetahuan/seberapa_penting_pelayanan_publik_ digit

al_cari_tahu_jawabannya_disini791\#: :text=Pelayanan\%20publik\%20digital\%20adalah\%20sol usi $\% 20$ untuk\%20mengubah\%20sistem,publik\%20digital\%20harus\%20segera\%20diaplikasika n\% 20untuk\%20kenyamanan\%20masyarakat diakses pada 5 Oktober 2021.

23 Tasmil. (2013). Pemeringkatan E-Government di Kota Makassar. Jurnal Pekommas. Volume 16 Nomor 3, hlm. 187.

24 Lihat Peraturan Presiden Nomor 95 Tahun 2018 tentang Sistem Pemerintahan Berbasis Elektronik. 
jaminan mutu layanan publik berbasis digital meningkatkan tingkat kepuasan dan kepercayaan masyarakat terhadap kemampuan dan manajemen pemerintah dalam menyelenggarakan pelayanan publik. ${ }^{25}$

\section{Urgensi Pengesahan Rancangan Undang-Undang Perlindungan Data} Pribadi Guna Menjamin Keamanan Data Digital Dalam Pelayanan Publik

Penyelenggaraan pelayanan publik berbasis digital selain memberikan manfaat dan dampak positif juga menimbulkan tantangan dan masalah baru terkait dengan jaminan perlindungan dan keamanan data digital. Masalah jaminan dan keamanan data digital disebabkan oleh konsekuensi logis dari penerapan sistem digital yang pada mulanya data dan informasi dikelola secara manual dalam bentuk surat dan dokumen, sedangkan pada sistem digital data dan informasi tersebut dialihkan dan diubah menjadi data digital.

Masalah jaminan dan keamanan data digital yaitu berkenaan dengan pengumpulan, pengolahan, pembagian, dan penyimpanan data ke dalam sistem komputerisasi. Pada umumnya, data digital yang disimpan dan dikelola berkaitan dengan kerahasiaan pribadi seseorang. Ada beberapa kategori yang termasuk ke dalam rahasia pribadi yaitu :26

1) keadaan anggota keluarga, dan riwayatnya

2) keadaan, model perawatan, riwayat, pengobatan kesehatan fisik, serta psikis individu

3) keadaan keuangan, rekening bank seseorang, aset, serta pendapatan

4) beberapa hasil evaluasi yang kaitannya dengan kemampuan manusia, kepandaian, serta rekomendasi kemampuan individu

5) notulensi yang kaitannya dengan privasi yang berhubungan pada aktivitas sekolah formal dan non formal nya.

Masalah keamanan data digital disebabkan oleh adanya tindakan ilegal berupa peretasan dan kebocoran data serta informasi digital seseorang. Hal ini dapat bermuara kepada penyalahgunaan data pribadi seseorang dalam melakukan tindak pidana berupa penipuan, pemerasan, pengajuan pinjaman secara ilegal, penjualan data pribadi seseorang, serta berpura pura sebagai pemilik data agar dapat mengakses berbagai kegiatan, misalnya untuk program sosial atau layanan kesehatan.

Salah satu contoh kasus kebocoran data pribadi digital yang berkaitan dengan layanan publik yaitu dialami oleh Badan Penyelenggara Jaminan Sosial atau BPJS Kesehatan. Bulan Mei 2021, sekitar 279 juta data masyarakat Indonesia yang ikut dalam BPJS Kesehatan dikabarkan mengalami kebocoran serta diperdagangkan pada laman raidsforum.com. Adapun data informasi yang bocor dan diperjual belikan meliputi data mengenai identitas kependudukan, nomor telepon, hingga gaji. ${ }^{27}$ Selain itu, kasus kebocoran data pribadi juga menimpa data nasabah BRI Life,

25 Dhion Gama Putra. (2017). Pengaruh Kualitas Pelayanan Terhadap Kepuasan Masyarakat (Studi pada Dinas Kependudukan dan Pencatatan Sipil Kota Blitar). Jurnal Administrasi Publik. Volume 3 Nomor 12, hlm. 2120.

26 Lihat Pasal 17 huruf h Undang Undang Nomor 14 tahun 2008 tentang Keterbukaan Informasi Publik.

${ }^{27}$ Andita Rahma. (2021). Data Penduduk di BPJS Kesehatan Bocor, Bukti Lemahnya Perlindungan Data Pribadi. https://fokus.tempo.co/read/1465176/data-penduduk-di-bpjskesehatan-bocor-buktilemahnya-perlindungan-data-pribadi/full\&view=ok diakses pada 6 Oktober 2021. 
terdapat kabar dijualnya data 2 juta nasabah BRI Life pada nilai $\$ 7.000$ atau kisaran Rp 101,6 juta. Selain itu, ada 463.000 surat yang diperdagangkan. Adapun data yang diperjualbelikan diantaranya berupa nomor rekening, nomor wajib pajak, rekam medis, dan akte kelahiran nasabah. ${ }^{28}$

Dengan adanya pengakuan akan Indonesia sebagai negara hukum, sudah seharusnya negara memberikan jaminan kehidupan dan perlindungan pada warganya. Pada hal ini bangsa wajib memberi perlindungan atas hak dasar masyarakatnya, salah satunya jaminan perlindungan data pribadi seseorang. Dalam konstitusi telah dijelaskan bahwasanya, setiap manusia memiliki hak terkait data pribadi, harkat, martabat, keluarga, dan harta benda kaitannya dengan perlindungan dan memiliki hak atas jaminan kemanan dari adanya rasa takut akan ancaman yang akan diberikan. ${ }^{29}$

Perlindungan diri pribadi memiliki keterkaitan dengan eksistensi terhadap hak hak privasi, yaitu bersangkutan dengan data data diri pribadi serta data yang berkaitan dengan kerahasian pribadi seseorang. Data pribadi adalah data yang menjadikan seseorang bisa terkenal/ teridentifikasi dengan langsung ataupun tidak, atas dasar berbentuk nomor atau lebih dari banyaknya faktor spesifik berupa identifikasi psikologi, batin, fisik, budaya atau sosial. ${ }^{30}$

Jaminan atas hak privasi data pribadi seseorang merupakan entitas dari eksistensi kebebasan dan harga diri seseorang. Perlindungan data pribadi sangat dibutuhkan di tengah besarnya pengaruh teknologi dan internet penting sehingga dapat mewujudkan kebebasan terkait dengan identifikasi seseorang. Dengan menjamin terlindunginya hak privasi seseorang menjadikan eksistensi manusia terjaga. ${ }^{31}$ yaitu: 32

Menurut Edmon Makarim, ada 3 prinsip penting terkait dengan hak privasi,

a. Setiap manusia berhak untuk tidak diganggu, kaitannya dengan kehidupan pribadinya. Misalnya kehidupannya tidak diusik oleh orang lain

b. Mempunyai hak kaitannya dengan rahasia beberapa informasi yang sifatnya sensitif berkaitan dengan dirinya

c. Hak atas kontrol data pribadinya yang dipegang oleh pihak lain

Sehingga peretasan, penyebarluasan, dan penyalahgunaan data pribadi merupakan suatu tindakan ilegal yang keluar dari prinsip hukum serta hak asasi individu, ini dikarenakan hak tersebut berkaitan dengan kebabasan memberi/ menolak data pribadi. ${ }^{33}$ Hal ini dikarenakan dalam konsep perlindungan data

28 Andita Rahma. (2021). Mabes Polri Siap Usut Kebocoran Data Nasabah BRI Life. https://nasional.tempo.co/read/1488274/mabes-polri-siap-usut-kebocoran-data-nasabahbrilife/full\&view=ok diakses pada 7 Oktober 2021.

29 Lihat Pasal 28G ayat 1 Undang Undang Dasar Negara Republik Indonesia 1945

30 European Union Agency for Fundamental Rights and Council of Europe, Handbook on European Data Protection Law. Belgium. 2014.

31 Sinta Dewi Rosadi. 2015. Aspek Perlindungan Data Pribadi Menurut Hukum Internasional, Regional dan Nasional. Bandung: Refika, hlm. 12.

32 Edmon Makarim. 2010. Tanggung Jawab Hukum Penyelenggara Sistem Elektronik. Jakarta: Rajawali Pers, hlm. 298-299.

33 Human Rights Committee General Comment No. 16 (1988). 
pribadi, seseorang mempunyai hak akan menetapkan kaitannya ia membagi atau menukar data pribadinya atau tidak.

Dalam pelayanan publik, jaminan perlindungan dan keamanan data digital menjadi penting dan harus mendapat perhatian oleh pemerintah. Hal ini karena bersinggungan dengan tingkat kepuasan dan kepercayaan publik dalam tata kelola pemerintahan, yaitu bagaimana pemerintah dapat menjamin terjalinnya sebuah sistem yang ideal sekaligus dapat melindungi hak privasi warga negara dari potensi kebocoran data pribadi. Diantara upaya yang bisa dilakukan oleh pemerintah guna melindungi data pribadi seseorang ialah membentuk peraturan hukum yang komprehensif.

Sejauh ini, aturan perundang-undangan yang membahas tentang privasi dan perlindungan serta pribadi seperti UU Perlindungan Konsumen, UU Informasi Transaksi Elektronik (ITE), UU Keterbukaan Informasi Publik, UU Perbankan, UU Telekomunikasi, UU Administrasi Kependudukan, UU Hak Asasi Manusia, Peraturan Pemerintah No 82 Tahun 2012 tentang Penyelenggaraan Sistem dan Transaksi Elektronik, Peraturan Menteri Komunikasi dan Informasi Nomor 20 tahun 2016 tentang Perlindungan Data Pribadi dalam Sistem Elektronik, dan peraturan perundang-undangan lainnya.

Dalam UU Administrasi Kependudukan dijelaskan di dalamnya data perseorangan yang sudah mereka lakukan perawatan, penyimpanan, serta penjagaan atas kebenaran dan perlindungan dari beberapa rahasia disebut dengan data pribadi. Pada hal ini, penyelenggara dan instansi pelaksana layanan administrasi kependudukan diwajibkan memberikan jaminan, kerahasiaan serta rasa aman atas data warga masyarakat. ${ }^{34}$ Kewajiban ini sebagai konsekuensi dari keberadaan kewajiban negara bukan cuma dalam hal penyimpanan data kependudukan, tetapi juga menjaga kerahasiaan data pribadi penduduk. Dalam penyelenggaraan pelayanan publik terkait dengan administrasi kependudukan, ada beberapa data pribadi penduduk yang harus dijaga dan diberi perlindungan kerahasiaannya, yakni nomor Kartu Keluarga (KK), Nomor Induk Kependudukan (NIK), waktu kelahiran, identitas orang tua, serta keterangan mengenai kondisi kesehatan baik fisik maupun mental. ${ }^{35}$

Tidak hanya diatur pada UU Administrasi Kependudukan, perlindungan data pribadi juga telah diatur dalam Undang Undang Kesehatan yang pada pokoknya menjelaskan kaitannya setiap individu ini memiliki hak atas rahasia keadaan kesehatan dirinya. Maka konsekuensi logisnya adalah penyelenggara layanan kesehatan wajib melindungi dan menjaga data data berupa rahasia kondisi kesehatan seseorang. ${ }^{36}$ Namun, meskipun data tentang kondisi kesehatan seseorang wajib untuk dijaga kerahasiaannya, tetapi terdapat pengecualian dalam UU Kesehatan yang diantaranya karena : 1) diperintahkan oleh UU ; 2) diperintahkan oleh mahkamah ; 3) adanya izin dari yang berkaitan; 4) kepentingan orang tersebut.

Sehingga dapat kita simpulkan bahwa pengaturan terkait dengan perlindungan data pribadi sejatinya sudah dirancang secara umum terdapat pada

34 Lihat Pasal 85 ayat (3) Undang Undang Nomor 23 Tahun 2006 tentang Administrasi Kependudukan sebagaimana telah diubah dalam Undang Undang Nomor 24 tahun 2013.

35 Lihat Pasal 84 ayat (1) Undang Undang Nomor 23 Tahun 2006 tentang Administrasi Kependudukan sebagaimana telah diubah dalam Undang Undang Nomor 24 tahun 2013.

36 Lihat Pasal 57 ayat (1) Undang Undang 37 Tahun 2009 tentang Kesehatan. 
beberapa ketetapan peraturan perundang undangan seperti disebutkan diatas, namun tidak dapat kita pungkiri bahwa hingga sejauh ini negara masih tidak memiliki aturan UU yang menaungi hal tersebut, terkhusus pada perlindungan data pribadi. Jika melihat pengaturan terkait dengan itu saat ini di Indonesia sudah ada, tetapi sifatnya masih parsial serta sektoral sehingga tidak sampai menyentuh suatu perlindungan yang maksimal, kaitannya pada data pribadi yang mana ini termasuk bentuk privasi. Dengan demikian, sangat penting menurut penulis untuk segera ditetapkan RUU Perlindungan Data Pribadi guna mencegah masifnya pelanggaran perlindungan data pribadi dan menambah tingkat efektivitas dalam melindungi data pribadi.

Jika kita melihat kepada UU No 12 Tahun 2011, bahwa kaitannya dengan aturan ini diharapkan dapat memberikan kepastian hukum dengan terbitnya Undang-Undang tersebut terasa sehingga sebuah aturan dapat lebih selaras abik dari segi substansi bahkan sampai sistematika kalimatnya. Sehingga kehadiran RUU Perlindungan Data Pribadi menyempurnakan aturan aturan terkait dengan yang telah ada sebelumnya.

RUU Perlindungan Data Pribadi dapat memberikan pengaturan dalam ruang lingkup kenegaraan yang di dalamnya ada beberapa prinsip umum perlindungan, pemrosesan yang sah serta penyebutan yang selaras kaitannya dengan pengurusan data pribadi. Selain itu, guna memberikan model pengelolaan pada setiap langkah pemrosesan seluruh jenis data pribadi baik yang ada di Indonesia bahkan mancanegara.

RUU Perlindungan Data Pribadi sebagai sebuah solusi terhadap permasalahan dari ketidaksinkronan UU sudah ada, yang sifatnya sektoral serta masih ditemukan rangkapnya peraturan yang membahas kaitannya perlindungan data pribadi. Legalitas yang sudah ada yang juga membahas kaitannya dengan ini masih belum adanya suatu kepastian hukum.

Aturan yang kaitannya dengan perlindungan data pribadi yang sudah dirumuskan pada RUU harapannya dapat mensejajarkan posisi Indonesia dengan bangsa-bangsa lain yang lebih awal mengimplementasikannya, maka memiliki pengaturan perlindungan data pribadi secara khusus dan baik. Hal ini akan tentu dapat mendorong negara lain untuk berinvestasi di Indonesia karena dengan adanya jaminan perlindungan data pribadi dalam penyelenggaraan pelayanan publik dapat membentuk iklim ekonomi yang sehat. ${ }^{37}$ Tetapi RUU ini juga memberikan perlindungan akan privasi serta data pribadi yang ditemukan dan tugasnya juga meminimalisir kesalahan dalam penyelenggaraan pelayanan publik.

\section{Simpulan}

1. Demi menyelenggarakan pelayanan publikyang baik dan profesional dalam mewujudkan smart government sebagai salah satu unsur smart city, maka digitalisasi dalam pelayanan publik memiliki peranan penting. Digitalisasi pelayanan publik menjadikan kualitas layanan semakin baik, profesional, cepat, mudah, terjangkau, serta efektif dan efisien. Hal ini yang menjadi

37 Sinta Dewi Rosadi. 2018. Perlindungan Privasi dan Data Pribadi dalam Era Ekonomi Digital di Indonesia. Jurnal Vej. Volume 4 Nomor 1, hlm. 100. 
perbedaan dengan pelayanan publik berbasis konvensional yang boros biaya, lama, berbelit belit, koruptif, diskriminatif, dan tidak responsif. Sehingga dengan adanya digitalisasi pelayanan publik dapat mereformasi penyelenggaraan pelayanan publik semakin baik dan terwujudkan tata kelola pemerintahan yang cerdas (smart government).

2. Demi menjaga keamanan data digital di tengah merebaknya kasus kebocoran data pribadi, penting bagi Indonesia untuk mempunyai pengaturan kaitannya perlindungan data pribadi secara khusus. Situasi ini karena pengaturan terkait perlindungan data pribadi yang sudah ada di Indonesia belum dapat menjamin dan melindungi kerahasiaan data pribadi warga negara. Hal ini karena pengaturan yang ada masih bersifat umum, parsial, dan ego sektoral sehingga belum dapat menjamin kepastian hukum perlindungan data pribadi secara optimal. Oleh sebab itu, penting bagi Indonesia untuk mempunyai aturan khusus terkait perlindungan data pribadi. Maka melalui disahkannya RUU Perlindungan Data Pribadi diyakini dapat menyempurnakan aturan tentang perlindungan data pribadi yang telah ada dan memberikan jaminan kepastian hukum yang optimal bagi perlindungan data pribadi warga negara.

\section{E. Saran}

Melalui jurnal ini, kami merekomendasikan kepada pemerintah dan lembaga perwakilan rakyat dengan meminta agar disahkan RUU Perlindungan Data Pribadi di Indonesia dikarenakan akan semakin memberikan jaminan perlindungan pada data pribadi di tengah masifnya perkembangan pelayanan publik secara digital.

\section{F. Referensi}

\section{BUKU}

Budhijanto, D. (2016). Revolusi Cyberlaw Indonesia Pembaharuan dan Revisi UU ITE. Bandung: Refika Aditama.

Dewi Rosadi, R. (2015). Cyberlaw Aspek Data Privasi Menurut Hukum Internasional, Regional, dan Nasional. Bandung: Refika Aditama.

Dewi Rosadi, R. (2015). Aspek Perlindungan Data Pribadi Menurut Hukum Internasional, Regional dan Nasional. Bandung: Refika.

Dwiyanto, A. (2005). Mewujudkan Good Governance Melalui Pelayanan Publik.Yogyakarta: Gajah Mada Press.

Ibrahim, J. (2007). Teori dan Metodologi Penelitian Hukum Normatif, Malang: Bayu Media.

Makarim, E. (2010). Tanggung Jawab Hukum Penyelenggara Sistem Elektronik. Jakarta: Rajawali Pers.

Marzuki, Peter Mahmud. 2011. Penelitian Hukum. Jakarta: Kencana Prenada Media Group. 
Nazir, M. (2005). Metode Penelitian. Jakarta: Ghalia Indonesia.

Nashuddin. (2016). Manajemen \& Kepemimpinan dalam Pelayanan Publik. NTB: Sanabil.

Novianty, D. (2018). Manajemen Pelayanan (Berbasis Revolusi Mental). Gorontalo: Ideas Publishing.

Sapri. 2020. Pelayanan Publik: Implementasi dan Aktualisasi. Pasuruan: Qiara Media.

Soekanto, S. (2007). Pengantar Penelitian Hukum. Jakarta: UI Press.

\section{PERATURAN PERUNDANG-UNDANGAN}

Deklarasi Universal Hak Asasi Manusia (DUHAM)/ Universal Declaration of Human Rights (UDHR).

Instruksi Presiden No. 3 Tahun 200 tentang Kebijakan dan Strategi Nasional Pengembangan E-Government.

Peraturan Presiden Nomor 95 Tahun 2018 tentang Sistem Pemerintahan Berbasis Elektronik.

Peraturan Presiden RI Nomor 95 Tahun 2018 tentang Sistem Pemerintahan Berbasis Elektronik (SPBE).

Rancangan Undang-Undang Perlindungan Data Pribadi (RUU PDP). Undang-Undang Dasar Negara Republik Indonesia Tahun 1945.

Undang-Undang No. 19 Tahun 2016 tentang Informasi dan Transaksi Elektronik. Undang-Undang Nomor 14 Tahun 2008 tentang Keterbukaan Informasi Publik.

Undang-Undang Nomor 24 Tahun 2013 tentang Perubahan atas Undang-Undang Nomor 23 Tahun 2006 tentang Administrasi Kependudukan.

Undang-Undang Nomor 25 Tahun 2009 tentang Pelayanan Publik.

JURNAL

Dewi Rosadi, S. (2018). Perlindungan Privasi dan Data Pribadi dalam Era Ekonomi Digital di Indonesia. Jurnal Vej. 4(1)

Gama Putra, D. (2017). Pengaruh Kualitas Pelayanan Terhadap Kepuasan Masyarakat (Studi pada Dinas Kependudukan dan Pencatatan Sipil Kota Blitar). Jurnal Administrasi Publik. 3(12)

Hasibuan, Abdur Razzaq \& Sulaiman, Oris Krianto. (2019). Smart City, Konsep Kota Cerdas Sebagai Alternatif Penyelesaian Masalah Perkotaan Kabupaten/Kota, Di Kota-Kota Besar Provinsi Sumatera Utara. Buletin Utama Teknik. 14(2)

Ramadhani, Wahyu. (2017). Penegakan Hukum Menanggulangi Pungutan Liar terhadap Pelayanan Publik. Jurnal Samudra Keadilan. 12(2)

Sautunnida. (2018). Urgensi Undang-Undang Perlindungan Data Pribadi di Indonesia: Studi Perbandingan Hukum Inggris dan Malaysia. Kanun Jurnal Ilmu Hukum. 20(2)

Tasmil. (2013). Pemeringkatan E-Government di Kota Makassar. Jurnal Pekommas. 16(3)

Utomo, Chandra Eko \& Hariadi. (2016). Strategi Pembangunan Smart City dan 
Tantangannya bagi Masyarakat Kota. Jurnal Strategi dan Bisnis. 4(2)

\section{ARTIKEL INTERNET}

Andita Rahma. 2021. Data Penduduk di BPJS Kesehatan Bocor, Bukti Lemahnya Perlindungan Data Pribadi. https://fokus.tempo.co/read/1465176/datapenduduk-di-bpjs-kesehatan-bocor-bukti-lemahnya-perlindungan-datapribadi/full\&view=ok diakses pada 6 Oktober 2021.

Andita Rahma. 2021. Mabes Polri Siap Usut Kebocoran Data Nasabah BRI Life. https://nasional.tempo.co/read/1488274/mabes-polri-siap-usut-kebocorandata-nasabah-bri-life/full\&view=ok diakses pada 7 Oktober 2021.

Andrian Pratama Taher. 2016. Rapor Merah Pelayanan Publik. https://tirto.id/rapor- merah-pelayanan-publik-di-indonesia-b8zr diakses pada 1 Oktober 2021.

Anonim. Pemerintah Berbasis Elektronik dan Pelayanan Publik.https://ombudsman.go.id/artikel/r/artikel--pemerintahan-berbasis elektronik-dalam-pelayanan-publik diakses pada 8 Oktober 2021.

Chris Fither. 2019. (Kebiasaan) Memaklumi Pungli.

https://ombudsman.go.id/artikel/r/artikel--kebiasaan-memaklumi-pungli diakses pada 3 Oktober 2021.

Lagat Parroha Patar. 2021. Proses Panjang Peningkatan Kualitas Nilai Pelayanan Publik di Indonesia. https://ombudsman.go.id/artikel/r/artikel--proses- panjangpeningkatan-kualitas-nilai-pelayanan-publik-di-indonesia diakses pada 3 Oktober 2021.

Lestarri Moerdijat, Perlindungan Data Pribadi, http://lestarimoerdijat.com/2019/10/05/perlindungan-data-pribadi/, diakses 8 Oktober 2021.

Rudy Rinaldy. Manfaat Teknologi Informasi dalam Pelayanan Publik. https://padang.go.id/manfaat-teknologi-informasi-dalampelayanan-publik diakses pada 1 Oktober 2021. 